Meta

Journal des traducteurs

Translators' Journal

\title{
Translation: The Relationship between Writer and Translator
}

\section{Kathy Mezei}

Volume 34, numéro 2, juin 1989

URI : https://id.erudit.org/iderudit/003647ar

DOI : https://doi.org/10.7202/003647ar

Aller au sommaire du numéro

Éditeur(s)

Les Presses de l'Université de Montréal

ISSN

0026-0452 (imprimé)

1492-1421 (numérique)

Découvrir la revue

Citer cet article

Mezei, K. (1989). Translation: The Relationship between Writer and Translator. Meta, 34(2), 209-224. https://doi.org/10.7202/003647ar d'utilisation que vous pouvez consulter en ligne.

https://apropos.erudit.org/fr/usagers/politique-dutilisation/ 


\section{TRANSLATION : THE RELATIONSHIP BETWEEN WRITER AND TRANSLATOR}

KATHY MEZEI

Simon Fraser University, Burnaby, British Columbia, Canada

\section{INTRODUCTION}

The following is an edited transcription of a panel discussion, "Translation: The Relationship Between Writer and Translator," that took place Friday, July 1, 1983 at the Women and Words Conference in Vancouver. The panelists, in order, are Cécile Cloutier, Gwladys Downes, Claudette Branchard, Barbara Godard, and Danielle Thaler. The moderator is Kathy Mezei*.

$\mathbf{K M}$ : The classic example in Canadian letters of a relationship between a writer and a translator is the correspondence between F. R. Scott and Anne Hébert, Dialogue sur la traduction (Montréal, 1970), which Doug Jones, the poet, described as two mandarins bowing to each other. ${ }^{1}$ I hope we can overcome the stiffness of mandarins bowing to each other. Let me outline the parameters of our discussion. Since the writers and translators in question are Québécois writers and translators and English-Canadian writers and translators, this discussion refers to a specific cultural context. In Canada, translation becomes a way of breaking down or breaking out of the "two solitudes." During the $1960 \mathrm{~s}$ and $70 \mathrm{~s}$, the translation of Québec novels of revolt and of the iconoclastic poésie du pays ${ }^{2}$ introduced English readers to the "quiet revolution" in culture and politics, while currently the "new writing" in Québec of feminists and post-modernists is slowly being translated, establishing a connection with English-Canadian feminists and postmodernists. ${ }^{3}$

Another question that insinuates itself into a discussion of the relationship between translator and writer is whether and how translation is important as a craft for those who also write poetry themselves. To address this, we have the perspective of the poet as translator (Gwladys Downes and Cécile Cloutier) and the poet as translated (Cécile Cloutier).

Since the act of translation is also an act of criticism, another factor in the relationship between the writer and translator is that the translator acts analytically as a critic and interpreter of the source text.

When the translators speak about their ideas on translation, they will inevitably refer to two crucial dilemmas involved in the act of translating. They will discuss the poles of translation which, as Gwladys Downes once wrote, "varies from the extremely free interpretation to practically one's own poem that has nothing to do with the original, to a literal fidelity that is often a joke, because it has no meaning in the target language." 4 The second dilemma, which is central to this entire conference, raises its head in a number of guises and concerns gender and sexual difference in translation: what differences occur when women translate men, women translate women, men translate women? Do women translate women authors differently from men? There has been an excellent paper arguing that they do. 5

And finally, moving to the literary institution of translation: how do women fare as professional translators? The question of translation as a profession brings me to an irre- 
sistible item I found in the Translators' Journal (janvier-mars 1964, 9:11, p. 3), entitled "Translating: An Ideal Profession for Women":

Translation is one of the few professional careers open to women with an interest and background in languages which need not be sacrificed at the altar of marriage or abandoned for the enchantment of motherhood. Once the necessary proficiency has been acquired, it can be pursued substantially without interference from either man or child. It will offer more rewards - material, intellectual, and emotional - than any other pursuit, with the possible exception of the one to which you have been unknowingly dedicating yourselves since nine months before your birth.

Whether that one pursuit is death or motherhood or wifehood, is unclear!

Notes

1. D. G. Jones (1971): “D. G. Jones/Fred Cogswell (Discussion : Eva Kushner and Yves Merzisen)," Ellipse, 21, pp. 98-101.

2. For example, novels by Marie-Claire Blais, Anne Hébert, Hubert Aquin, Roch Carrier, Jacques Ferron; poetry in translation has appeared in Ellipse (Sherbrooke, Universite de Sherbrooke, 1969-) and also in Glassco's The Poetry of French Canada in Translation (Toronto, Oxford University Press, 1970). Guernica Editions and Véhicule Press are publishing bilingual editions of contemporary writers including Claude Beausoleil, Jean-Yves Collette and Juan Garcia.

3. Nicole Brossard (1983): These Our Mothers, trans. Barbara Godard, Toronto, Coach House Press. See also Louky Bersianik (1978): The Eugelionne, trans. Gerry Denis et al., Victoria, B.C., Press Porcépic; Nicole Brossard (1979) : les Stratégies du réel / The Story So Far 6, Toronto, Coach House Press.

4. G. V. Downes (1973): "Preface," When We Lie Together, Vancouver, Klanak, pp. 9-10.

5. Evelyne Voldeng (1984): "La traduction poétique: duplication ou dérivation textuelle d'une langue à une autre?" la Traduction : l' universitaire et le praticien, Ottawa, Éditions de l'Université d'Ottawa, pp. 151159.

CÉCILE CLOUTIER was born in Québec, and teaches in the French Department at the University of Toronto. She has published seven volumes of poetry; a selection of her poems was translated as Springtime of Spoken Words (Toronto, Hounslow Press, 1979), by Alexandre Amprimoz. She was recently involved in a translation experiment in Ellipse 29/30 (1982), and is now translating the poet Robert Zend.

I would like to say some words about the way I feel about the text when it is translated.

Alors, pour une écrivaine, être traduite comporte beaucoup de beauté, autant intellectuelle que psychologique, des beautés de la pensée comme des beautés de cœur. Alors, c'est un peu comme être bilingue. S'ajouter une langue, c'est mettre une valeur dans sa vie, une importance quotidienne et chaleureuse, et aussi des amitiés. C'est, en un sens, augmenter l'intelligence de son texte. En principe on a plus de choses à comprendre dans deux systèmes que dans un. On s'habitue à voir les différences et on prend souvent conscience de la valeur des mots en les traduisant. J'ai fait des expériences où moi aussi j'ai traduit des choses; puis j'ai fait une anthologie de poésie ukrainienne, il y a quelques années, qui a été publiée chez Déom à Montréal. Alors, j'ai travaillé un peu dans ce senslà. Il s'agit en fait de sens que l'on ne voit pas si on ne parle qu'une langue. Il est très difficile pour un livre comme pour un individu de s'intégrer sérieusement dans le temps s'il n'a pas comparé son présent, son passé et son futur avec ceux des autres, ceux d'une autre langue. Être bilingue ou multilingue pour un poème, c'est sentir profondément qu'on ne vit en relation, en équilibre qu'avec les autres. C'est peut-être aussi, comme 
pour un individu, être beaucoup moins certain de ce que l'on est. C'est prendre conscience, jusqu'au fond de soi, de l'autre, de l'altérité. C'est s'aventurer, c'est avant tout une disponibilité, une ouverture d'esprit. C'est une invitation et une sacralisation de la parole, de même qu'une façon de la faire accourir à sa signification. Psychologiquement c'est pour l'auteur comme un amour, c'est une main que l'on tend. C'est aussi allumer un feu. Cela consiste à être conscient des signes. Il s'agit d'une manière tendre d'être sensible, d'accueillir le monde, de s'échanger en lui. C'est atteindre l'autre, et aussi attendre l'autre. C'est pour le traducteur, la traductrice, une longue patience et un dur travail d'attachement. La traduction demande beaucoup de discipline et exige que l'on croie au langage. Il faut s'adapter à la vérité d'un autre mot et détruire ses habitudes, avoir le don du commencement, la capacité de vivre la première fois, de l'accepter profondément tout au fond de soi, tout au fond de son texte, avec un goût très simple et très sûr de l'expérience. On doit aussi avoir un respect immense du silence qui est dans le texte. Et on doit être prêt à le peupler, de même qu'à considérer l'arrivée du nouveau comme une création, et être disponible au "happening". Car il faut croire au présage et espérer dans l'avenir. L'autre langue devient une perfection, une façon d'être plus complet, plus achevé. Mais elle peut aussi établir une inquiétude et l'auteur traduit et traduite peut se sentir menacé par l'intrusion de l'autre dans son texte. Mais peut-être que la traduction est avant tout un acte de connivence qui convient à celui qui est capable de posséder, de s'enrichir et d'augmenter.

GWLADYS DOWNES, retired professor of French at the University of Victoria, is the author of Out of the Violent Dark (Victoria, B.C., Sono Nis Press, 1978), which contains all her translations from Québec poets as well as most of her original poems up to that date. She has translated the Québec poets Roland Giguère, Alain Grandbois, Rina Lasnier, Saint-Denys-Garneau, Anne Hébert, André Major, Yves Préfontaine, and PaulMarie Lapointe.

For all my life I have had a love affair with two languages - the one I was born into and the second that I acquired (more or less, as I do not call myself totally bilingual), at about the age of twenty. When I learned my French, I was not encouraged to do it through translation; the professors and other people I was working with disapproved of translation. They had come from an academic tradition which emphasized it almost as an end in itself, and they disagreed, feeling that such an approach paralysed the capacity for creative or natural thought in the second language. So I had it drummed into me for many years that I must forget my English if I were speaking or thinking in French. For many years, therefore, I kept my two languages apart; when I heard Shakespeare in French, it made me shudder (and still does). When I read a Racine text in English, it was even worse.

The result of this conditioning was that I disapproved of the idea of translating French poetry into English ; prose I could not have cared less about, but poetry was really important to me. However, as a political necessity in the sixties I did get involved, much against my inclination, with translation. An insistent colleague who was also an editor kept after me, and finally came up with, "Well, write me a poem in English that will just give readers an idea of what these people are talking about." So I gave in, although I disapproved. 
He handed me two poems by Rina Lasnier, who was my age and had grown up intellectually in the same French literary tradition. She was working and thinking in symbols, in sharp images, and using a dense, compact syntax. Her language, in the best critical sense, was pure and uncluttered. I found the main images in these poems rather exciting - one a comparison of suicides with sailors, ${ }^{1}$ the other a more indirect equating of the soul and the scarecrow. ${ }^{2}$ The latter word in English is, of course, fascinating with many resonances, so the minute I got these fundamental concepts, something started happening - I began hearing combinations of words in my own mind which seemed the equivalent of the emotions in the poem. Since I do not think easily in formal patterns, I discarded the French metres (it was in alexandrines, which I do not particularly like), and simply tried to enter into the experience.

Somewhat to my surprise, I got hooked on this. I thought it was the most fascinating literary work I had ever done. You give your voice to someone else and you are impersonal about it; you are not worrying about your own psyche, you are concerned for someone else's. You are merely an interpreter, a clear pane of glass for the truth of the poet's experience to shine through. Now, as I went on from these poems to others, I discovered that there are different kinds of translation, the first of these being my rather freewheeling one. Shortly after doing these poems, just by chance, I found Frank Scott's translations of Anne Hébert and Saint-Denys-Garneau. ${ }^{3}$ Scott, an extremely able poet himself, managed to produce translations which were both accurate and poetic, faithful to content and form. This became an ideal, though frankly, I had never considered it possible to be both literal and true to the original text. So my second attempts at translation aimed at closely reproducing the original pattern, at least in the matter of long and short lines and stanza form. I never attempted to make anything rhyme, but I did try to keep the syntax as close as possible to the French.

It is the different syntax, which produces problems we all come up against in dealing with poetry in two languages. Frank Scott, I discovered, had chosen poems that worked well in English, and when I looked at the others he had not chosen, I found they did not work (in that technique) because there were immediate complications, knots of language and thought, emotions and expressions, which simply did not transfer easily. While I still think the ideal is worth while pursuing, it is not possible for all poetic texts.

What did I do them? John Glassco was asking me to prepare some translations for him to be included in his anthology of Québec poets, ${ }^{4}$ so this gave me the opportunity to experiment with a third kind of technique, which consisted of starting with Scott's method of literal translation, keeping as close as possible to the text to find out the exact meaning of every word, its resonances and suggestive qualities. Once I had a basic form, I would let it lie fallow for a while, and then see if some spontaneous rhythm or sound or line would come up, even if it entailed trying a different order. My personal computer, left to itself, does come up with surprises. The final form is a blend of the two approaches. My point of view for anyone else is that if you have to be free, be free, but the ideal is not to be completely free because that is not fair to the poet.

Even the experienced translator, let alone the unwary one, finds all kinds of traps in syntactical differences between the languages. But one should not betray the original, no matter what the temptation to glide over the problems. Above all, one should not add one's own ideas to the subject, however interested one is in the theme. Summing up, one should be absolutely faithful to the writer, whether it is a man or a woman.

Kathy Mezei was talking just now about the question of the "creative effect" of translation. I can think at the moment of only two or three of my own poems which were influenced by translations. The first one was written when $I$ had just returned from France, where $I$ had been working on the subject of "Paul Valéry en face du symbolisme 
et du surréalisme", in the course of which I had had to study intensely two of his most famous poems and their translations into English, Italian, and Spanish. So I had in my consciousness a very dense kind of poetic texture, every syllable counting for something both musically and linguistically - "La Jeune Parque" 5 - if you like. One of my own poems was half-consciously influenced by that model, but when I looked at it ten years later my reaction was "That's not English, it's French."6 I was not completely aware that at the time of writing, I was transferring a perfectly legitimate French technique into English.

The other examples are more recent. When I was reading Anne Hébert - I have not translated many of her poems, one poem, that I did not translate because John Glassco did not require it, had a mirror image in it which turned up very quickly in one of my own poems. It is a short poem, called "Mirror, Mirror,"7 and I am using exactly the same image but for another end, another experience, another meaning. As far as the handling of language goes, I was trying to produce something as transparent, as elegant, as precise, as evocative as she did. And I knew when I was writing it that that was what was happening. That is the only one I can put my finger on. Recently, however, one verse of a poem almost came out in French. I was up in the Queen Charlotte Islands on a huge beach; sea, sand, sun, middle of the day - and you can see what that combination is going to bring you into: Paul Valéry's "le Cimetière marin"8, one of the two poems I mentioned before - and when I was finally writing a poem ${ }^{9}$ about this experience (it is a fairly long poem for me), I found right in the middle that there were four lines which suddenly started going into French because there was a similar association of sea and sun with death. There is a dead whale on the beach in my poem which is not in "le Cimetière marin", but this train of thought brought me to words which reflected a clarity in the Mediterranean tradition rather than the Northern one which infuses the English language and imagination.

To go back to the question of one's attitude as a translator to poems by men and poems by women - I have never thought of making any distinction. A woman may, as Kathy has demonstrated, have a slight edge over a man in translating some feminine experiences, but I suspect the degree of linguistic sensibility on the part of the individual concerned may play just as important a role as gender. I have never, when translating, thought of myself as anything but an impersonal voice, although I can see that a woman's experience is certainly valuable in translating poems by other women.

Notes

1. Rina Lasnier (1960) : "Les suicidés," "Silves (suite)," Mémoire sans jours, Montréal, Éditions de l'Atelier.

2. Rina Lasnier (1960): "L'épouvantail," "Silves," Mémoire sans jours, Monțréal, Éditions de l'Atelier.

3. F. R. Scott (1962): St. Denys-Garneau and Anne Hébert, Vancouver, Klanak Press.

4. John Glassco (1970): The Poetry of French Canada in Translation, Toronto, Oxford University Press.

5. Paul Valéry: "La Jeune Parque," in CEuvres complètes, édition établie et annotée par Jean Hytier, Paris, Gallimard, 1962.

6. G. V. Downes (1955): "Tzouhalem (Lines on a Painting by Max Maynard)," in Lost Diver, Fredericton, Fiddlehead Press.

7. G. V. Downes (1973) : "Mirror, Mirror," in When We Lie Together, Vancouver, Klanak Press.

Mirror, Mirror

soft birds are dying

in the long room

under sea-green splinters

of wild glass

a dark and deadly

conjunction of planets

diverted an antic star, 
crazing the blue reflections :

yours, these shattered eyes

now you move carefully

among the birds

not to disturb

their dying

Anne Hébert (1960) : "Vie de château," in Poèmes, Paris, Éditions du Seuil.

Vie de château

C'est un château

Sans table ni feu

Ni poussière ni tapis.

L'enchantement pervers de ces lieux

Est tout dans ses miroirs polis.

La seule occupation possible ici

Consiste à se mirer jour et nuit.

Jette ton image aux fontaines dures

Ta plus dure image sans ombre ni couleur.

Vois, ces glaces sont profondes

Comme des armoires

Toujours quelque mort y habite sous le tain

Et couvre aussitot ton reflet

Se colle à toi comme une algue.

$S^{\prime \prime}$ ajuste à toi, mince et nu,

Et simule l'amour en un lent frisson amer.

8. Paul Valéry: "Le cimetière marin," in CEuvres complètes, édition établie et annotée par Jean Hytier, Paris, Gallimard, 1962.

9. G. V. Downes (1982): "Flotsam at Rose Point," Canadian Literature, 94, Autumn, p. 113.

CLAUDETTE BRANCHARD, a Franco-Ontarian living in Montreal, works as a translator for a Montreal-based term financing company. She has translated many of Sharon Nelson's poems, which have been broadcast on CBC, and choreographed and presented at dance performances in Montreal and is currently translating Sharon Nelson's Man Women and Crazy Ladies (Dewittville, Québec, Sunken Forum Press, c1983).

I am very glad that Women and Words has decided to pay attention to translation, since one of the problems of the profession is that it is becoming a women's ghetto. According to Judy Woodward, past director of the translation programme at Concordia University, ninety-two percent of the undergraduates in the translation programme during the past three years were women. Similarly, although you would find a lot of women in lower-level translation jobs in industry, they are woefully underrepresented in management. Another of the problems encountered in the profession is the exploitation of the talent women are supposed to have for translation. Many employers, especially during the recession, are now requiring that clerical workers do translation. Female graduates of undergraduate translation programmes are accepting jobs as secretaries and being exploited and underpaid, whereas the male graduates would never accept such work, although I am told that this, too, is slowly changing because of economic conditions. However, male graduates most often lack the clerical skills required to be secretaries.

As Kathy has pointed out, I translate the work of Sharon Nelson. I have an ideal situation because Sharon and I were close friends for a number of years before I started translating her work, more or less by accident. Sharon's poetry was choreographed by 
Gabrielle Orbach for the Dance in Canada conference. It went very well and Gabrielle wanted to present it to other audiences in Montreal. Of course, you need a French text for a Montreal audience. I agreed to do the translation, although my first impression was like Gwladys', that you don't translate poetry, and I had always sworn I would never try it. I had taken literary translation courses and anything I had had to do with poetry was a disaster. I didn't really want to touch it, but since Sharon was my friend, I said, "Well, I'll do it and you'll see it's awful and we'll just forget about it and remain friends." We started with a couple of poems that Gabrielle had choreographed, and in fact it worked out so well that they decided to read the poetry in French.

How do we work together? One has to know the degree to which Sharon understands French. According to the Office de la langue française, she would rate about a " 2 ," a perfectly bilingual person being a " 5 " and somebody completely unilingual being a "1." Because of this, we can work very closely together without her influencing me unduly. I always assumed this was the only way to do it and now I am suddenly confronted with the fact that it is indeed very rare. Usually we work on more than one poem at the same time just in order to vary a bit. I will translate the poems, and once I am reasonably satisfied with them, I can't sleep until I discuss it with her, so very quickly we sit down and have a session. I read the poem to her in French because she is very sensitive to the rhythm, especially since the ones that we had originally done were for a dance performance. She listens to the sound and the rhythm and then she'll say, "All right, now tell me what it means." In effect, what I am doing is taking my translation and translating it back into English for her. Then she picks out the errors. I also end up having to translate all kinds of French dictionary entries for her. We make lists of possible words that could be used. We could, I suppose, come up with a much freer translation which would probably be perfectly adequate, but I try to keep as close as possible to the original, first, because I don't presume to change Sharon Nelson's poetry, and secondly, because I feel that this approach is important, although I don't put down anybody who likes to do experimental work. Because this is a more or less official version of Sharon Nelson's poetry, I don't want to produce something too experimental, except perhaps in the course of developing the work when we sometimes play around with ideas that are unorthodox.

Some problems come up. As I say, Sharon knows enough French to argue with me sometimes, but not enough to understand completely what I'm trying to get at. I do not think our friendship has gotten in the way of our work so far. Sometimes cultural differences which we are not aware of in our personal relationship suddenly surface: Sharon is Jewish and I am a French-Canadian Catholic which leads to interesting situations. A lot of her work is about the Jewish experience, especially the experience of Jewish women but many poems have recently been about the experience of Catholic women in Québec in a traditional, very closed, conservative situation. One cultural difference that people sometimes forget is an age difference. Sharon is only ten and a half years older than I am, but this can create a tremendous gap, because Sharon doesn't always perceive that there are things I don't know about because I was not yet born or was a very small child when they happened.

One of the experiments I do as a writer in relation to translating Sharon's work this is going to be a revelation to her today — is that I imitate her style in English. I write poems similar to her own, playing around with different ideas, sometimes almost a spoof. In a way translation is a form of imitation; it's also a form of flattery. But this helps me to have a feel for the style, both in English and in French, when I translate her work. I try to remain as supple and flexible as possible and this experiment helps me, although I would never dare to publish such a monstrosity! 
One of the sad things about the process of educating translators is that we are losing sight of the fact that the translator is also a writer. Certain undergraduate programmes are trying to produce "language filtration agents," and insist on very practical matters that are necessary in industry; but even in industry you have to know how to write. In the translation programme at Concordia, literature courses are slowly being replaced by courses with extremely technological-sounding names, which I doubt are producing any better or more useful translators than the older programmes. We must not lose sight of the fact that it is, after all, an intellectual profession, not a technical one, and that if there were more serious literary translation being taught in universities, both industry and literary translation would benefit.

BARBARA GODARD ${ }^{1}$ is editor of the Coach House translation series, and has made current Québec feminist writing available to English-Canadian readers through her own translations of Antonine Maillet, Louky Bersianik, Yolande Villemaire, and Nicole Brossard (These Our Mothers, Toronto, Coach House Press, 1983). Barbara also translated a number of Cécile Cloutier's poems as part of a study by Evelyne Voldeng of the textual variations of male and female translators. ${ }^{2}$

I want to talk to you today briefly about the illicit pleasures of translating. Before I define what I mean by illicit pleasures, I would like to suggest that we look at the theory of translation because I think that this may be a way of getting out of the impasse that Claudette has just mentioned of seeing translation as a mechanical act. It is an advantage in current theory that changes are taking place. Generally, translation is conceived as involving the rendering of a source language (SL) text into the target language (TL) so as to ensure that (1) the surface meaning of the two will be approximately similar, and (2) the structures of the SL will be preserved as closely as possible, but not so closely that the TL structures will be seriously distorted. In this view, translation is perceived as a secondary, imitative activity, as a mechanical rather than a creative process. A general anti-theoretical tradition in the Anglo-Saxon world has perpetuated a view of such a "servant-translator."3 Hence, of course, you can get secretaries doing the translations. Anybody, with the aid of a dictionary, can move from one language into another. That such a view has been dominant in Canada would be suggested by the fact that no study of translation graces the pages of the Literary History of Canada; only in the last four years has one been included in the annual University of Toronto Quarterly's Letters in Canada. This latter occurrence indicates a revalorization of translation which is now being granted the dignity of original (rather than subsidiary and derivative) work.

For a long time there has also coexisted an opposite view of translation, stressing the pre-eminence of the translator's creative freedom. In earlier periods translation was regarded as a serious and useful method for helping a writer explore and shape her native style. Contemporary tendencies defining translation as an art, not a craft or science, draw sustenance from new work in linguistics by Russian formalists and semioticians. More than just a transference of "meaning" from one set of language signs to another through competent use of the dictionary and grammar, the process of translation involves a whole set of extra-linguistic criteria. The translator is an active participant in the creation of meaning, there being a substitution of TL meanings for SL meanings. ${ }^{4}$ An entire culture and system of aesthetic features must be interpreted for a new audience. Consequently, "a translation is not a monistic composition, but an interpenetration and conglomerate of 
two structures."5 Translation becomes "one of the most difficult tasks that a writer can take upon (her)self." The translator becomes a co-creator with the writer in a relationship that may be described as Author-Text-Receiver = Translator-Text-Receiver. ${ }^{6}$ Like the author, the translator sends a message to the reader to be decoded, but this translator is simultaneously reader of another's message which she is decoding in order to recode. Limits to the translator's creative freedom are extended in this act of reading to the boundaries of the original text. At the same time, however, the reader is stimulated to greater activity, encouraged to become an active producer of meaning, through the equation of reading/translating. Contemporary reader-reception theories postulating an active reader of literary texts encourage this. As George Steiner suggests, any act of reading is an act of translation, 7 for we are continually crossing linguistic boundaries in our own language, making leaps through time and space in order to approach the Metaphysicals or Shakespeare, traversing the frontiers of sexuality, if one is a woman reader, in order to interpret the work of Hemingway or Mailer. The essence of language is its translatability or it would not function as a system of signs. Comprehension involves the translation of a work into our own idiolect and of putting ourselves into the place of the speaker. The case for the creativity of such communicative activity has been well formulated by writers. In the words of Octavio Paz, all texts are "translations of translations of translations." One could expand on this idea in terms of theories of intertextuality by saying, as Paz does, that "every text is unique and, at the same time, it is the translation of another text."8

It is against the background of such theories of dynamic communication that my own translation practice has evolved. In the course of translating the works of women writers I was pushed into an active relationship with their words. For those writers were constantly attempting to find new sources of meaning for women within language, meanings heavily dependent on the cultural context of their being women and speaking the language of a minority excluded from the encodings of culture in our systems - grammars and dictionaries. In no way could their works be translated with the simple help of a dictionary, for the meanings I was to recode were not to be found there. The search for and invention of ways to communicate these new meanings are the source of the "pleasures" I obtain from translation, and from them I gain not just a sense of the riches of the writers' texts, but, as Cécile has said so eloquently, the sense of moving into another world, into something which is familiar and yet so tremendously different, and where one's sense of being is greatly enlarged, where a deeper understanding of the resources of my own language and of my own experience is developed. In a sense it is for these reasons that I started to translate, to help to separate myself when I was living in a bilingual experience, to try to find out exactly what were the resources of my own language and from where I was speaking. By probing the differences between my experience and that found in the texts of writers such as Nicole Brossard, Louky Bersianik, Yolande Villemaire and Cécile Cloutier, to name a few of the more challenging explorations of language I have attempted, I discover that unknown other that is within me. These very real delights of discovery are the source of my emotional investment in translating. But self-discovery is only one of the pleasures. The other major one is the ludic one of playing with the multiple meanings of words. Granted, I have chosen texts where punning was a major stylistic device, thus accentuating the ludic possibilities. But translating itself has long seemed like a game to me. It has been one of my most pleasurable intellectual experiences. From the time I was in school I just loved doing sight translations on exams : to be put down in front of something I had not seen before with a limited space of time and to go to work on it. It is an experience I have often equated with doing a puzzle, 
for many of the constraints are similar. One has a picture already drawn; one needs to interpret and complete it. The drive to fill in the blanks and to get just the right-shaped piece into the space is compulsive.

The puzzle analogy offers another perception into the act of translating for it underlines the different approaches which may be taken. One can fit the pieces in by using guides of colour and design or one can turn the puzzle over and use shape alone. Similarly, in translating, one must keep both semantic and formal (rhyme, metre, etc.) systems in mind as producers of meaning in the total text. Moreover, the word "puzzle" translates as "casse-tête," a phrase with other, darker associations. One may indeed "break one's head" on the translation and one is most certainly "breaking the text" in translating it. These darker notes are related to the "illicit" element in the act, especially as it relates to the translator/writer bond. However, most of the bliss of the language is that of the translator's, as the edge of her idiolect comes up against that of the author's style. For it is the author who has taken the risks of creation, expounded the ideas, plots and characters and made the dangerous expedition into the unknown, bringing forth her insights for the scrutiny of the world.

The shadows over the pleasure stem from the nature of the relationship between translator and writer, who are doubles, with all of the psychic weight that attends to being that monstrous other self. Or, as I like to imagine it, the translator is a ventriloquist, a mouthpiece, a voice for the writer in another language; the translator is also an accomplice in smuggling something from one culture to another. Both analogies underline the complicity between writer and translator; both point to the somewhat subversive activity of translation, the stealing, copying or imitating of an original work of art. But both also point to the limitations of the translator's activity, its failure to produce equivalence. When I described my translation as the work of a ventriloquist, I was referring to a series of poems where I had deliberately sacrificed sense to sound, choosing to make the texts sound like the work of Brossard. ${ }^{9}$ Incidentally, I was also underlining their untranslatability. As the Italian proverb has it, every translator is a traitor, because complete equivalence in the sense of sameness cannot take place in translation. Only creative transposition is possible from one language to another; each remains unique, for languages are modelling systems, the heart within the body of culture, and convey their own cultural contexts. Inevitably, at some level, the translator will be unfaithful to the text being translated. For while the words of one culture may be found in another, the function and value of these words will change. (This slippage of meaning exists within subcultures, too, and in this respect the writing of women, representing a subculture within a culture, poses additional difficulties in translation.)

Let me give just one example of the associative riches left behind in translation. In Don l'Orignal, Maillet refers to a "sawesse," 10 which she spells phonetically, and which is deciphered easily as the English word "sou'wester." While in English this refers to a type of waterproof hat worn by fishermen, in Acadian dialect it means any hat worn peak backwards and may include hats worn this way by lumberjacks who use the peak to protect them from snow down their necks. Here the original function and value of the word are expanded when the word moves into French, reduced when it returns to English again. Each language represents a separate reality and attempting to bring one across linguistic frontiers is a subversive action.

While I have talked about the dangers here, and the problems that one is always steering between - fidelity on the one hand, which is a form of treachery, and freedom on the other, which is another form of treachery - there are perhaps gains to be had through translation, because texts may be expanded and clarified through translation. This is something which, of course, poses dangers for the writer and I have an entry for 
February 3, 1983 from a journal by Nicole Brossard ${ }^{11}$ that I would like to read, in my translation, where she talks about just this aspect of being translated and the threat that this poses for the writer.

I spent the entire day reading the English translation of $l$ Amèr for which Barbara Godard sent me the final draft. Exhausting work it is to read the translation of one's own text. Exhausting, because the mental operations carried out in writing the text are added to the process that I would call unveiling. Because what we choose to hide in the text must now be unveiled. What, for example, the critic can only presume, dream or imagine as the meaning in what she reads, the translation seeks to verify. In this authentification I must face what I had consciously and scrupulously hidden. To be translated is to be the subject of an inquiry not only into what one believes oneself to be but also into the way of thinking in a language, and the way we are thought of by a language. This makes me question that other I might be if I thought in English, or Italian or any other language. What law, what morality, what landscape, what picture would come into my mind then? And who would I be in each of these languages? What would being a woman in Italian involve? What relationship would I have with my body if $I$ had to think about it in English ? [...] The question translation, like writing, raises if that of choice. What signifier to choose to activate a surface of multiple signifieds which, invisible and effective, vibrate in the space of consciousness?

Notes

1. This essay is being published in a slightly different version in In the Feminine: Women and Words / les Femmes et les mots (Longspoon Press, 1985). We gratefully acknowledge Longspoon Press's permission to publish this version.

2. Evelyne Voldeng (1984): "La traduction poétique : duplication ou dérivation textuelle d'une langue à une autre," in la Traduction, l'universitaire et le practicien, Ottawa, Éditions de l'Université d'Ottawa, pp. 151159.

3. Susan Bassnett-McGuire (1980): Translation Studies, London, Methuen, p. 3.

4. J. C. Catford (1965): A Linguistic Theory of Translation, London, Oxford University Press, pp. 32-37.

5. Jiri Levy, quoted by Bassnett-McGuire, p. 5 .

6. Bassnett-McGuire, p. 38.

7. George Steiner (1975): After Babel: Aspects of Language and Translation, London, Oxford University Press, p. 27 and indeed the entire chapter, "Understanding as Translation."

8. Octavio Paz (1971): Traducción: Literatura y Literalidad, Barcelona, Tusquets Editor, p. 9, quoted in Bassnett-McGuire, p. 38.

9. B. Godard (1982) : "The Translator as Ventriloquist," Prism International, XX, 3, Spring, pp. 35-36. To be rpt. in the special 25th anniversary issue, Fall 1984.

10. Antonine Maillet (1972): Don l'Orignal, Montréal, Leméac, p. 76. The Tale of Don l'Orignal, trans. by B. Godard, Toronto, Clarke Irwin, 1978.

11. Nicole Brossard (1984) : Journal intime, Montréal, les Herbes rouges, pp. 22-23, Godard's translation.

DANIELLE THALER was born in Paris, emigrated to Canada in 1971, and teaches at the University of Victoria. She has been involved in theatre and radio, has published a volume of poetry, called Poèmes à deux voix (Toronto, s.n., c1980), and translates children's books from English into French.

Tout d'abord, je voudrais dire que quand j'ai commencé à faire de la traduction, c'était pour des raisons nettement moins intellectuelles et poétiques que mes collègues. J'étais étudiante à l'époque, et il s'agissait surtout d'un expédient pour gagner un peu d'argent...

Et je dis bien «un peu» d'argent, parce que j'ai été consciencieusement exploitée par les bureaux de traduction, ce qui je crois arrive à tous les débutants. En fait, cela n'a pas été totalement négatif, puisque j'ai eu l'occasion de toucher un peu à tout en passant du domaine de l'agriculture, à celui de la chaussure bon marché, sans oublier les polices 
d'assurance et on m'a même proposé de m'occuper de la section française d'une revue pornographique. On ne mentionnait guère les relations avec l'auteur. S'il y a une chose qu'on ne m'a jamais demandé à l'époque, c'était de m'occuper de traduction littéraire, et pour cause, puisque ce genre de travail ne serait absolument pas rentable pour un bureau de traduction. Disons qu'un traducteur qui est doté d'une certaine expérience peut se constituer dans un temps record, un lexique en soudure, en mécanique. Les personnes qui font de la traduction littéraire savent que cela ne s'applique absolument pas dans ce domaine-là, sauf peut-être pour les romans dans le genre «Harlequin Romances». J'ai d'ailleurs eu l'occasion de rédiger quelques promotions pour ces romans et quand on a écrit dix fois : «La belle hérö̈ne au cœur tendre retrouvera-t-elle ce jeune homme séduisant qui lui promettait monts et merveilles?» on s'en lasse vite, je vous assure.

Puis j'ai commencé à travailler pour la télévision, surtout la télévision éducative, et aussi pour des programmes audio-visuels, programmes de formation professionnelle. Et là, j'ai eu droit à tout un apprentissage parce que non seulement il s'agissait de traduire ou d'adapter un texte, mais il fallait prendre en considération l'image, le bruitage, le décor et aussi parfois, travailler avec les acteurs, une fois qu'on avait en main le texte français. Alors, si on veut parler à ce niveau-là, de relation entre auteur de scripts et traducteur, je dirais que dans mon cas c'était souvent très frustrant, non pas à cause de la personne qui avait écrit le script original, mais à cause des conditions de travail, parce qu'on travaillait par ébauches successives, donc quand on essayait de monter le texte en anglais il fallait presque parallèlement refaire le texte en français, et tout changeait tout le temps, à cause du réalisateur, bien entendu. Et il fallait travailler extrêmement vite, faire des retouches, parfois considérables, en un temps minime.

Une chose entraînant l'autre, j'ai commencé à m'intéresser aux livres d'enfants, à cause justement de mon expérience avec l'image, parce que dans le livre d'enfant, surtout chez les tout petits, en fait c'est l'image qui est porteuse de sens; les mots et les images se répondent et sans l'image le texte aurait une tout autre signification. Souvent même c'est l'adulte qui lit aux petits, donc il faut penser à l'image sonore, c'est le son qui devient très important. Au début, $\mathrm{j}$ 'ai traduit un petit peu de tout dans les textes de littérature enfantine et puis un moment est arrivé où je me suis posé la question: «mais, c'est quand même curieux, je suis toujours en train de traduire des textes qui proviennent d'Angleterre ou qui proviennent des États-Unis, est-ce qu'il n'y a rien qui s'écrive au Canada?» Et je me suis aperçue que du moins dans les dix ou vingt dernières années, s'il y avait beaucoup de production dans les deux langues il y avait très peu de traduction. En 1967, qui est déjà une année record de la production de littérature enfantine au Canada, il y avait sept traductions. Il y a cu beaucoup d'amélioration dans les dernières années, surtout je crois à cause de l'aide du Conseil des arts. Des bourses sont accordées aux éditeurs pour promouvoir la traduction des textes d'une langue officielle dans l'autre.

J'étais assez surprise au début de voir qu'un texte québécois de littérature enfantine avait finalement plus de chance d'être lu dans un pays francophone que dans les provinces anglophones du Canada. Bien qu'il s'agisse du même pays, il y avait très très peu de circulation. Alors une des satisfactions pour moi justement quand je traduis des textes écrits au Canada anglophone, c'est de les voir circuler de l'autre côté. De plus, ces derniers temps, même ici à Vancouver, à cause des programmes d'immersion, on réclame à cor et à cri des livres avec un contenu non seulement canadien, mais un contenu local. Et là, en ce qui concerne la relation entre traducteur et auteur, je me heurte encore une fois à des problèmes difficiles. Par exemple, je viens de terminer un texte qui s'intitule en français la Mère et le cèdre, texte qui traite des Indiens de la côte du Nord-Ouest. En anglais, ce texte est utilisé au grade sept, huit. On m'a dit: «il faut adapter le texte au 
grade quatre pour l'immersion en français». Il est à peu près impossible dans ces conditions de respecter le texte, ce qu'un éditeur unilingue ne comprend pas, et ce que l'auteur prend fort mal.

Je suis contente de voir que la littérature enfantine a enfin acquis des lettres de noblesse, parce que pendant longtemps, on l'a considérée comme de la petite littérature, à côté de la grande, celle qui est réservée aux adultes. L'éditeur, lui, me demande toujours la même chose, à savoir, un texte simple, clair, précis : il faut produire un texte qui passe partout. Comme plusieurs personnes l'ont dit ici, idéalement la traduction devrait jeter un pont entre les cultures et que ce qui compte, c'est la transposition des représentations. Mais, comme on l'a dit également, c'est fort délicat car la représentation des personnages et de leur entourage non seulement coïncide rarement d'une culture à l'autre, d'une langue à l'autre, mais, le problème se pose aussi à l'intérieur de la même langue. En guise de conclusion, et pour appuyer mes déclarations, $j$ 'aimerais vous faire passer une minute d'un petit enregistrement. C'est un conte à ce que j'appellerais deux têtes, deux voix, et multiples images.

Dans toutes les villes bien sûr les gens vivent pas de la même façon selon le quartier, ou la ville de banlieue qu'ils habitent. Alors à ce sujet-là, j'ai l'histoire de deux petits garçons à vous raconter. Et pour ce faire, j'ouvre mon livre des contes:

Il était une fois un petit garçon qui habitait à Outremont et qui s'appelait Jean-Claude. Son papa était gérant du personnel à la Canadian Bakers.

Une fois c'tait un 'ti gars qui restait dans l'est. Y s'appelait Ti-Claude. Son père v'nait d'perdre sa job à Bakers.

Jean-Claude avait un frère et deux sœurs.

T-Claude y'avait cinq frères pis huit sœurs.

À l'école privée, en plus de sa langue maternelle, Jean-Claude étudiait une langue de travail : l'anglais.

À l'école Saint-Jacques en troiseiéme année B, Ti-Claude y'apprenait une langue seconde : le français.

Parfois lorsqu'il avait désobéi à la bonne, la maman disait à Jean-Claude : «Pas de dîner pour toi ce soir mon chéri, monte dans ta chambre». Elle parlait comme une actrice.

Des fois quand Ti-Claude était tannant, le bonhomme y disait «T'écoute pas quand on te parle. Tu mangeras pas à soir, comme d'habitude. Monte te coucher dans le garde-robe. $\grave{A}$ soir t'as congé, couche dans le coffe de cédre. Ferme le couvert.»

Jean-Claude habitait une magnifique maison en haut de la montagne.

Ti-Claude restait dans un shack en bas d'la track.

Jean-Claude aimait beaucoup s'étendre sur la pelouse pour regarder le soleil, le ciel bleu, et les nuages blancs.

Ti-Claude y'aimait ben ça des fois s'asseoir su'a chaîne du troittoir, pis regarder le gros nuage gris.

Chez Jean-Claude à Noël, on mangeait de la dinde, des canneberges, des pommes de terre mousselines, et une excellente bouteille de Château-Gruot-La-Rose 1964.

Chez Ti-Claude, à Noël y mangeait d'la dinde, des atacas, des patates pilées avec un trou en haut pour mette la sauce, pis un bon Kik 1971.

(Tiré des «Cyniques»)

Comme vous le voyez, en guise d'adaptation, nous, les traducteurs, n'avons que l'embarras du choix. 


\section{DISCUSSION}

KATHY MEZEI - I have a question for Sharon Nelson. ${ }^{1}$ This concerns the relationship between the writer and the translator, where the writer is aware of his or her future translator. Roch Carrier said that when he was writing his novels which Sheila Fischman subsequently translated, he sometimes asked himself how she would translate this or that. As you are writing poems are you thinking of your translator, Claudette (Branchard)?

SHARON NELSON - No. I can be absolutely definite about that. I have to admit that my own writing process is akin to diving into a very deep pool and eventually surfacing. I don't believe that I am thinking of anyone at that time. I am dealing with the technical problem of translating what it is that I wanted to say into the form by which one is bound, as Barbara has said. After all, there are constraints in translating the feeling and the thought into whatever it is you are doing. No, I have enough trouble with my own thoughts. I never worry about Claudette or anyone.

KATTHY MEZEI - You never think, "I wonder what she'll do with this word ?"

SHARON NELSON - No. But first of all I should say, in defence of my own French, that my "kitchen" French is excellent. In working with Claudette, I have become more aware of my own writing on a technical level. I have always been perhaps more conscious than a lot of writers about what I am doing at a theoretical level, but in working with Claudette and doing these bizarre translations into French, back in English, back into French, it is fascinating to see how far you can push towards a meaning. You begin to understand the implications of a choice of language in English ; English words tend to be translatable into French in many ways. We can take the same image and work it in different ways and it becomes much clearer to me where my emphasis was and what I really intended. There are certain things that are just so obviously wrong, even though they are dead accurate, that I hate it; but why do I hate it if it is accurate? Sometimes the translation is better than the original, because you have had two minds at work on it and you have had further exploration. To work with the material for choreography was like taking a trip to the moon, because Claudette was bound by sound and rhythm, since the dancers were using the text as music, and she did not have a syllable to spare. It had to be syllable for syllable. It had to contain the meaning and make sense; it had to be something that sounded right to my ear. I don't know how this was ever accomplished, but it has meant that the work that we have done together has perhaps been a lot tighter than it might otherwise have been. I found this sort of cross-media evolution fascinating and I recommend it. If you are ever doing translation, certainly in poetry, think of it as being something that someone is going to use for choreography. You have a whole new set of problems, but you also have a rhythmic faithfulness that is absolutely wonderful and, considering the differences in English and French, just remarkable.

QUESTION FROM THE AUDIENCE - You raised the question of difference, of women translating men and men translating women. I was quite surprised. It never occurred to me that there could be a difference, except in a particular genre like feminist writing.

KATHY MEZEI - Let me give you an example. This comes from Evelyne Voldeng's paper "La traduction poétique. Duplication ou dérivation textuelle d'une langue à une autre?" in which she compares Barbara Godard's and Alexandre Amprimoz' translations of Cécile Cloutier and attributes their differences to gender. ${ }^{2}$

BARBARA GODARD - This was a paper that was given at the Learned Societies of 1980 during a three-day workshop on translation. Evelyne was looking at the whole question of the rift in meaning, the shift in meaning, given a number of different 
situations. She was comparing translations of works by poets and non-poets and the question of the sex of the translator. She had a number of examples drawn from several different passages. My part in this experiment was to translate certain marked poems by Cécile (Cloutier) from Chaleuils. ${ }^{3}$ I was not to look at any of the work that Alexandre Amprimoz had already done on Cécile's work, so I had no idea of the approach he was taking. I was to work from the texts themselves. She asked Alexandre to translate the same poems; then she put them together. There are about twenty translated poems in all, of which she used these two in her analysis. What she focused on was that there was much greater precision in the sensory information in my translations, such as the difference between "I felt" and "I smelled." She found that women were more concrete and the men more abstract when it came to choosing a cognate.

QUESTION FROM THE AUDIENCE - And how does Cécile feel about this?

CÉCILE CLOUTIER - Well, I have never compared translations. This was the first time I saw these ones and I was very interested. But I wanted to say "I smelled," and not "I felt"; Barbara is right.

GWLADYS DOWNES - I wonder if I could add something to what you were saying, that you had not thought of the question of difference of sex in translation.

SPEAKER FROM THE AUDIENCE - I was looking at it as a mental process. This is appealing to me and I understand that it is real to work with. I can feel akin to a male or female writer regardless of my own sex. However similar to me the woman writer can be, if as a translator I don't follow her mental process, I'm lost.

GWLADYS DOWNES - I agree with you. I had not thought of this until it was brought to my attention. I simply thought of myself as a translator, period. Asexual, almost. However, I did get a comment from a Québec poet that he hadn't known I was a woman because I had used initials (G. V. Downes); he was very surprised that a woman could translate one of his poems. That was the first time I had ever come across the fact that there was possibly a difference. I must say I haven't thought about it often since, because I don't translate from a feminine or feminist point of view, I just do the best I can with the material in front of me.

SAME SPEAKER FROM THE AUDIENCE - I don't think it applies only to feminists. I know that if I translate a male writer, I really identify with him and even my choice of vocabulary, terminology can be very different, not because I know he is a man, but because this comes through in the English. As a translator, I will be producing it in the French. If I get into a good relationship with a writer, I can tell you which adverbs this person is going to use, and it has nothing to do with their sex, but more with this choice of words or personal terminology. I think that is what the role of the translator is, to really perceive.

KATHY MEZEI - But there are certain things that one sees that the other doesn't. The example I always give is of Frank Scott's translation of Anne Hébert's poem "Le tombeau des rois," where the narrator is very clearly a woman. At one point she says "cette enfant fut-elle liée par la cheville"), which Scott translates without any indication that the speaker is a girl. In Dialogue sur la traduction ${ }^{4}$ Anne Hébert points this out to him and he resolves the problem in the poem by saying "her ankle" instead of "the ankle." I can't say that a woman would necessarily be more aware of that, but certainly other male translators of this poem have fallen into the trap of ignoring the persona's gender. 5

BARBARA GODARD - Some of the examples that Evelyne actually used were things that I find in my own editing (in Coach House Press, Translation Section). I was having to make corrections and changes because men hadn't caught references to bodily 
secretions and to things for which they just didn't know the terminology. It depends on the translator, probably in their familiarity, particularly in the case of contemporary writing, with the sexual world of the opposite sex and the language of that relationship.

BARBARA GODARD - There is one thing I would like to say before we finish. Danielle was talking about editors asking her to do things and giving her very specific limitations and constraints within which to work. However, most of the rest of us were talking in terms of friendship and of an on-going dialogue between friends, or a text that we were electing to translate, and in which we were investing a certain amount of emotional and / or creative energy. These may be two poles in the situation of translation. There may be variants in between, but it's really important to be aware of the different ways in which one would speak about the act of translation, depending on its relationship to the marketplace.

Notes

1. Sharon Nelson, a Montreal poet, is managing editor of Metonymy Productions, a company that specializes in technical literature. She is also a partner in the Feminist Research and Editorial Group. Mad Women and Crazy Ladies (Dewittville, Québec, Sunken Forum Press, 1983), is her most recent collection of poems.

2. Evelyne Voldeng (1984): "La traduction poétique. Duplication ou dérivation textuelle d'une langue à une autre ?" in la Traduction: l'universitaire et le praticien, eds. Arlette Thomas et Jacques Flamand, Ottawa, Éditions de I'Université d'Ottawa, pp. 150-159.

Poèmes de Cécile Cloutier (Chaleuils), traduits par Alexandre Amprimoz et Barbara Godard:

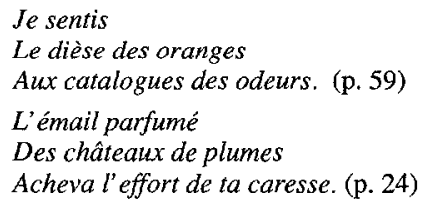

I felt

The sharps of oranges

In the catalogue of scents.

The scented enamel

of feather castles

Ended the effort of your caress.

A. Amprimoz
I smelled

Sharps of oranges

In the catalogues of scents.

The perfumed enamel

of feather castles

Completed the effort of your hand.

B. Godard

3. Cécile Cloutier $(1978,1979)$ : Chaleuils, Montréal, l'Hexagone.

4. Anne Hébert et F.-R. Scott (1970): Dialogue sur la traduction à propos du "Tombeau des rois", Montréal, éditions HMH.

5. "Neither Alan Brown nor Alfred Poulin, Jr. acknowledge the child as female in their translations ; [Peter] Miller, who read the Dialogue, does." Kathy Mezei (1984): "The Scales of Translation" in University of Ottawa Quarterly, vol. 54, no. 2 (April-June), p. 7. 